\title{
OVERVIEW OF CYNODON DACTYLON (DOOB GRASS) IN MODERN MEDICINE AS ANTIDIABETIC HERB .
}

\author{
*Das Mukesh Chandra ${ }^{1}$, Shilpi Shama ${ }^{2,}$ Chandra Satish $^{3}$ \\ ${ }^{1}$ Junior Resident, Department of Pharmacology, Rajendra Institute of Medical Sciences, Ranchi, Jharkhand, India \\ ${ }^{2}$ Tutor, Department of Physiology, MGM Medical College Jamshedpur, India \\ ${ }^{3}$ Professor, Department of Pharmacology RIMS, Ranchi,Jharkhand, India \\ *Corresponding Author's Email: drmchandra2011@gmail.com
}

\begin{abstract}
According to WHO About 347 million people worldwide have diabetes, and is predicted to become the seventh leading cause of death in the world by the year 2030.According to Diabetes Atlas 2012, released by 'International Diabetes Federation' India has 63 million people living with diabetes and is only second to China. By 2030, India's diabetes burden is expected to cross the 100 million mark as against 87 million earlier estimated. Many oral hypoglycemic agents, such as biguanides and sulfonylurea are available along with insulin for the treatment of diabetes mellitus but they have significant side effects and sometimes they are found to be ineffective in chronic diabetic patients. Since ancient times, diabetes has been treated orally with several medicinal plants or their extracts. Phytochemical study shows the presences of flavonoids and sterols in Cynodon dactylon(Doob Grass) which exhibit hypoglycemic activity and are also known for their ability of beta cell regeneration of pancreas. Sterols have also shown to decrease blood sugar in experimental animal models.
\end{abstract}

Keyword-diabetes, hypoglycaemic drugs, cynodon dactylon.

\section{INTRODUCTION}

Cynodon Dactylon (Doob grass) ${ }^{1}$ is the sacred grass next to Ocimum sanctum, (tulsi) because it is used to feed the cows which are sacred in india. The Sanskrit name of Doob is durva means which is cut or eaten by the animal. The plants sacred to lord Sankara, Ganesa and Visnu are vilva, durva and tulsi, which alleviate vata, pitta and kapha dosas, respectively. Hindus worship the God Ganesa with the leaves durva religiously. This plant has been recognised for its cooling, haemostatic, diuretic, and tonic properties since ancient times, cited in Dhanvantari, Kaiyadeva and Raja Nighantus. Ayurvedic texts mention two types of durva viz. white and green.According to Ayurveda, India's traditional pharmacopoeia, Cynodon plant is pungent, bitter, fragrant, heating, appetizer, vulnerary, anthelmintic, antipyretic, alexiteric. It destroys foulness of breath, useful in leucoderma, bronchitis, piles, asthma, tumors, and enlargement of the spleen. In Homoeopathic systems of medicine, it is used to treat all types of bleeding and skin troubles., ${ }^{2,3}$ Doob grass originally came from the savannas of Africa and is the common name for all the East African species of Cynodon. It is called bermuda grass in the United States because it was introduced from the Bermuda Island. In ancient Roman days they squeezed the juice from the stems and used it as a diuretic and astringent to stop bleeding.

\section{Detail of plant}

Botanical name: Cynodon Dactylon

Family: Poaceae

Genus: Cynodon $N$

Species: Dactylon

(C) 2011, JDDT. All Rights Reserved
Synonyms: ${ }^{4}$ Durva grass, Bermuda grass, Dog's Tooth grass,

Indian Doab, Scutch grass, Bahama grass,

Devil's grass, Couch grass, Hariyali Grass.

English Name: Bermuda grass, Bahama grass. ${ }^{5}$

Hindi: Doob

Sanskrit: Durva

HABITAT-Doob Grass is found throughout the world. It is grow in warm climates between $30^{\circ}$ south and $30^{\circ}$ north latitude.

MORPHOLOGY - Doob grass is a creeping grass, light green in color and has a coarse texture. It has three parts $\mathrm{i}$; $\mathrm{e}$ root,stem and leaves. It is fast growing and its root grows where ever a node touches the ground, forming a dense mat. It also reproduces from roots under the ground. It has a deep root system, in drought situations the root system can grow 47 to 59 inches $(120-150 \mathrm{~cm})$ deep. Most of the root mass lies 24 inches $(60 \mathrm{~cm})$ under the surface. Its blades are a gray-green color and are short, usually 1 to 4 inches $(3-10 \mathrm{~cm})$ long with rough edges. The erect stems can grow 0.3 to 1.3 feet $(0.1-0.4 \mathrm{~m})$ tall. The stems are slightly flattened, and an inflorescent purple in color. It has no odour and has a sweet mucilaginous taste ${ }^{6}$

Chemical composition of Doob Grass- 
It contains essential oil triticin $12.4 \%$. The other chemical constituents are glycosides, saponins, tannins, flavonoids and carbohydrates. It also contains agropyrene, arunodin, furfural, furfural alcohol, s $\beta$-ionine, 2-(4'hydroxy phenyl) propionic acid, 2-(3'methoxy-4'hydroxy-phenyl) propionic acid, 3-methoxy-4-hydroxy benzoic acid, phytol, $\beta$ sitosterol-D-glucoside, stigmasterol acetate, phago stimulant phytone (6,10-14-trimethyl pentadecane-2-one). Cuticular wax contains triacontane, docosanol. tetracosanol, hexacosanol, octacosanol, eicosanic acid \& docosanoic acid . ${ }^{7,8}$

Part Used- Whole plant and its root stalk is used for medicinal purpose. ${ }^{9}$

\section{TRADITIONAL USES}

Cynodon dactylon is used as a folk remedy for diarrhea, bronchitis, anasarca, calculus, dropsy, hemorrhage, urogenital disorders, cough, headache, sores, cancer, carbuncles, convulsions, cramps, cystitis, dysentery, epilepsy, hemorrhoids, leucoderma, hypertension, hysteria, asthma, tumors, measles, rubella, snakebite, stones, tumors, warts, wounds, eye disorders weak vision and Dandruff. It is also useful against pains, inflammations, toothache and grippe in children. The expressed juice of plant act as astringent and is applied to bleeding cuts and wounds to stop bleeding. The paste made of the plant mixed with honey is used in epitaxis. Oral administration of the juice of the plant with honey 2-3 times a day for few days effective treats menorrhagia. Local application in the form of paste of the plant extract upon the lower abdomen reduces severe bleeding in vagina. A decoction of Cynodon dactylon mixed with sugar is useful in the problem of urine retention. ${ }^{10,11,12}$

\section{Pharmacological action of $C$. dactylon}

\section{Part/Extract}

Rhizome Extract:

Hydro Alcoholic:

Aqueous :

Aqueous- Non polysaccharide fraction

Ethanolic :

Hydro Alcoholic :

Rhizome :

Aqueous :

Shoot : Immunomodulatory \&DNA Protective ${ }^{21}$

Ariel Part : $\mathrm{CNS}^{22}$

Aqueous : Chemo preventive ${ }^{20}$

Aqueous : Cytotype-specific ${ }^{23}$

Hydroalcoholic: Protection from ionizing Radiation cytogenetic damage ${ }^{24}$

50\% Aqueous-Ethanolic Extract: Nephrolithiasis (Kidney

Decoction :

\section{Biological Action}

Anti Inflammatory ${ }^{13}$ Cardio Protective ${ }^{14}$ Anti Diabetic ${ }^{15}$

Anti Diabetic ${ }^{16}$ Anti Diabetic ${ }^{17}$

Anti Arrhythmic ${ }^{18}$ Diuretic ${ }^{19}$ Antioxidant ${ }^{20}$

\section{Anti-diabetic activity}

Santosh kumar and coworkers (2009) evaluated the anti diabetic activity of aqueous extract of Cynodon dactylon at the doses of 250,500 and $1000 \mathrm{mg} / \mathrm{kg}$ body weight. The dose of $500 \mathrm{mg} / \mathrm{kg}$ was identified as the most effective dose. It lowers blood glucose level around $31 \%$ after $4 \mathrm{~h}$ of administration in normal rats. The same dose of $500 \mathrm{mg} / \mathrm{kg}$ produced a fall of $23 \%$ in blood glucose level within $1 \mathrm{~h}$ during glucose tolerance test (GTT) of mild diabetic rats. This dose has almost similar effect as that of standard drug tolbutamide $(250 \mathrm{mg} / \mathrm{kg} \mathrm{bw})$. Severely diabetic rats were also treated daily with $500 \mathrm{mg} / \mathrm{kg}$ bw for 14 days and a significant reduction of $59 \%$ was observed in fasting blood glucose level. A reduction in the urine sugar level and increase in body weight of severe diabetic rats were additional corroborating factors for its antidiabetic potential. Total cholesterol (TC), low density lipoprotein (LDL) and triglyceride (TG) levels were decreased by 35 , 77 and 29\%, respectively, in severely diabetic rats whereas, cardioprotective, high density lipoprotein (HDL) was increased by $18 \%$. The findings clearly indicate that aqueous extract of Cynodon dactylon has significant anti diabetic potential along with significant hypoglycemic and hypolipidemic effects..$^{15}$

Jarald E.E and costaffs (2008) found that the aqueous extract of $C$. dactylon Pers. and the non polysaccharide fraction of aqueous extract were found to exhibit significant anti hyperglycaemic activity and only the non polysaccharide fraction was found to produce hypoglycemia in fasted normal rats. Treatment of diabetic rats with aqueous extract and non polysaccharide fraction of the plant decreased the elevated biochemical parameters, glucose, urea, creatinine, serum cholesterol, serum triglyceride, high density lipoprotein, low density lipoprotein, haemoglobin and glycosylated haemoglobin significantly. Comparatively, the non polysaccharide fraction of aqueous extract was found to be more effective than the aqueous extract.$^{16}$

N. Mahesh and D. Brahatheeswaran,(2007) found that When aqueous and ethanolic extract of Cynodon dactylon was administered to glucose loaded normal rats fasted for $18 \mathrm{~h}$, hypoglycemia was observed after $30 \mathrm{~min}$. The decline in blood sugar level reached its maximum at 2 hour. $^{27}$

\section{Other pharmacological action}

\section{Cardio protective activity}

Garjani. A. and the costaffs (2009) evaluated the rhizomes of Cynodon dactylon were used for the treatment of heart failure in folk medicine. C. dactylon exerted a strong protective effect on right heart failure, in part by positive inotropic action and improving cardiac functions.$^{14}$

\section{Anti-arrhythmic activity}

Najafi. M. alongwith Gajrani A.(2008) investigated probable antiarrhythmic effects of $C$. dactylon against ischemia/ reperfusion (I/R)-induced arrhythmias in isolated rat. ${ }^{18}$

\section{Anti-inflammatory activity}


Cynodon dactylon is one of the 10 auspicious herbs that constitute the group Dasapushpam in Ayurveda. Traditionally Cynodon dactylon L. is used against many chronic inflammatory diseases in India . ${ }^{28,29}$

\section{Wound Healing:}

Druva gritha was evaluated by charde for wound healing property by incision and excision wound model in male wister rat promotes wound contraction and reduces the time for closure showing healing potential comparable to Framycetin sulphate $1 \%$ cream. $^{30}$

\section{Antidiarrheal:}

In an investigation hexane, dichloromethane, ethyl acetate and methanol extracts of Cynodon dactylon whole plant were tested in albino rats for antidiarrheal activity on castor oil induced diarrhea. ${ }^{31}$ Methanolic extract exhibited considerable reduction in inhibition of castor oil induced diarrhea and also showed a significant decrease in gastrointestinal motility. These results indicate that the plant possess good antidiarrheal property.

\section{Antiviral:}

Cynodon dactylon exhibited potent antiviral activity against white spot syndrome virus (WSSV) and they have also been reported to possess antiviral activity against human vaccinia virus. ${ }^{32}$

\section{Antiulcer:}

Alcoholic extract of Cynodon dactylon was screened for antiulcer activity in albino rats at dose level of 200, 400 and $600 \mathrm{mg} \mathrm{kg"1}$ b.wt. The extract at $400 \mathrm{mg} \mathrm{kg"1}$ and 600 nig kg"1 showed significant (>0.001) antiulcer activity as compared to the standard drug, ranitidine. This activity may be due to the presence of flavonoids. ${ }^{33}$

\section{Diuretic activity}

Plants extract increased significantly urinary output and electrolytes excretion at the dose of $0.500 \mathrm{~g} / \mathrm{kg}$ for C.dactylon. Aqueous herb extracts particularly, at the dose of $0.500 \mathrm{~g} / \mathrm{kg}$ induce significant effect on urinary output of water and electrolytes and justify their use as diuretic remedy in traditional medicine ${ }^{19}$

\section{Central Nervous System related activity}

The dried extracts of aerial parts of Cynodon dactylon Pers. were evaluated for CNS activities in mice. The ethanol extract of aerial parts of C. dactylon (EECD) was found to cause significant depression in general behavioral profiles in mice. $^{22}$

\section{Immunomodulatory activity}

Mangathayru K. and coworkers investigated the freshly prepared juice of Cynodon dactylon for its effect on doxorubicin-induced DNA damage in vitro and its immunomodulatory activity. Oral administration of the juice at 250 and $500 \mathrm{mg} / \mathrm{kg}$ in mice increased humoral antibody response upon antigen challenge, as evidenced by a dose-dependent, statistically significant increase in antibody titer in the haemagglutination antibody assay and plaque forming cell assay.$^{21}$

\section{Antioxidant activity}

The antioxidant, antiproliferative and apoptotic potentials of the plant were investigated by 1,1-diphenyl-2picrylhydrazyl (DPPH) assay, nitric oxide radical scavenging activity (NO(-)) and MTT assay on four cancer cell lines (COLO 320 DM, MCH-7, AGS, A549) and a normal cell line (VERO) ${ }^{20}$

\section{Chemo-preventive activity}

Albert-Baskar A. evaluated in vivo chemo -preventive property of the plant extract of Cynodon dactylon in DMHinduced colon carcinogenesis. The methanolic extract of $C$. dactylon was found to be antiproliferative and antioxidative at lower concentrations and induced apoptotic cell death in COLO 320 DM cells. Methanolic extract of $C$. dactylon increased the levels of antioxidant enzymes and reduced the number of dysplastic crypts in DMH-induced colon of albino rats. ${ }^{20}$

\section{Anti-nephrolithiasis activity}

Aqueous-etanolic extract of Cynodon dactylon can reduce calcium oxalate stones in the rat kidney by 40 and $55 \%$ respectively. It has beneficial effects on kidney stone removal and might be used in human beings ${ }^{25}$

Atmani. F. and coworkers evaluated the effect of Cynodon aqueous extract as a preventive and curative agent in experimentally induced nephrolithiasis. ${ }^{26}$

\section{SUMMARY AND CONCLUSION}

As the diabetes has become a global burden and long term management with available pharmacological therapy is gradually getting costlier, sometime ineffective as well as associated with side effects, it is desirable to explore the kinetics and action of herbal medicines like cynodon dactylon etc,for safe and effective management of diabetes. As researches shows the hypoglycemic action of cynodon dactylon is due to presence of flavinoid and sterols which regenerate beta cell of pancreas ,it might be very useful in treatment of diabetes. Beside hypoglycaemic action it also has antioxidant action which has addative effect in treatment of diabetes. As the Doob Grass is easily available, abundant in our region, very economical and easily recognisable, it is feasible to conduct the experimental work and results obtained would be very helpful for designing the large clinical trials before applying the results for the management of diabetic population. 


\section{REFERENCES}

1. Kirtikar KK, Basu BD. Indian Medicinal Plants, Vol.2, $2^{\text {nd }}$ edn. Lalit Mohan Publication, 1935,2650.

2. Ghosh, N.C. Comparative Materia Medica. Hannemann Pub., Co. Pvt. Ltd,1998.pp: 855.

3. Oudhia, P., B.S. Joshi and V.K. Kosta. The possibilities of preparing homeopathic drugs from the obnoxious weeds of Chhattisgarh. Bhartiya Krishi Anusandhan Patrika,1998. 13: 5357.

4. Mukherjee, Pulok K. Quality Control of Herbal Drugs 2002. Business Horizon, 2-34, 97, 98, 181-195, 248, 249, 562-567.

5. The wealth of india, Raw materials, 1st supplement series, CSIR, Vol. 2 page no.331-332

6 .Wallis TE: Text book of Pharmacognosy, Plant profile for Cynodon dactylon (Bermudagrass) USDA Plants.html, 5th ed. Vol.-II, p. 243-244.

7. Trease And Evans, Textbook of Pharmacognosy, Elsevier; 15th ed. p. 204-205, 479.

8. The wealth of india 2nd supplement series, Raw materials, CSIR, Vol. 1 page no.331-332.

9. Kritikar, K.K. and B.D. Basu, Cynodon dactylon. In: Indian Medicinal Plants. 2nd Edn., International Book Distributors, Dehradun, 1980.88 .

10. Chopra, R.N., Nayar S.L., Chopara I.C., Council of Scientific and Industrial Research (CSIR), 1st Edn., Council of Scientific and Industrial Research (CSIR), New Delhi, 1999., 88-89.

11. Rajakumar N., Shivanna M.B., Ethno-medicinal application of plants in the eastern region of Shimoga district,Karnataka, India. J. Ethnopharmacol. 2009, $126,64-73$.

12. Saikia A. P., Ryakala Venkat K., Sharma P., Goswami P., Bora U., Ethno botany of medicinal plants used by Assamese people for various skin ailments and cosmetics. J. Ethnopharmacol. 2006., 106,149-157.

13. G. Sindhu; M. Ratheesh; G. L. Shyni; A. Helen,Department of Biochemistry, University of Kerala, Kariavattom, Thiruvananthapuram 695 581, India: Inhibitory effects of Cynodon dactylon L. on inflammation and oxidative stress in adjuvant treated rats.

14. Garjani A, Afrooziyan A, Nazemiyeh H, Najafi M, Kharazmkia A, Maleki-Dizaji N.,BMC Complement Altern Med. 2009 Aug: Protective effects of hydroalcoholic extract from rhizomes of Cynodon dactylon (L.) Pers. on compensated right heart failure in rats.

15.Santosh Kumar Singh, Prashant Kumar Rai, Shikha Mehta, Rakesh Kumar Singh and Geeta Watal, Indian Journal of Clinical Biochemistry, Volume 24, Number 4 / October, 2009: Assessment of Anti diabetic Potential of Cynodon dactylon extract in Streptozocin diabetic rats.

16. Jarald EE, Joshi SB, Jain DC., Antidiabetic activity of aqueous extract and non polysaccharide fraction of Cynodon dactylon Pers. Indian J Exp Biol. 2008 Sep;46(9):660-7.

17. Santosh Kumar Singh, Achyut Narayan Kesari, Rajesh kumar Gupta,Dolly Jaiswal, Geeta Watal.,Alternative Therapeutics unit, Drug Discovery \& Development Division, Medicinal Research Laboratory, Department of Chemistry, University of Allahabad, Curative effect of Cynodon dactylon against STZ induced hepatic injury in diabetic rats.
18. Najafi M., Nazemiyeh H., Ghavimi H., Gharakhani A., Garjani A. DARU Vol. 16, No. 4 2008: Effects of hydroalcoholic extract of Cynodon dactylon (L.) pers. On ischemia/reperfusion-induced arrhyth- mias.

19. Sadki C, Hacht B, Souliman A, Atmani F.,J Ethnopharmacol. 2010 Mar 24:Acute diuretic activity of aqueous Erica multiflora flowers and Cynodon dactylon rhizomes extracts in rats.

20. Albert-Baskar A, Ignacimuthu S.,Exp Toxicol Pathol. 2009 Jul 10: Chemo preventive effect of Cynodon dactylon (L.) Pers. extract against DMH-induced colon carcinogenesis in experimental animals.

21. Mangathayaru K, Umadevi M, Reddy CU.,J Ethnopharmacol. 2009 May 4: Evaluation of the immunomodulatory and DNA protective activities of the shoots of Cynodon dactylon.

22.Pal D.Acta Pol Pharm. 2008 Jan-Feb: Evaluation of CNS activities of aerial parts of Cynodon dactylon Pers. in mice.

23. S K Sachdeva and M S Bhatia, Plant Sciences, Volume 89, Number 3 / June, 1980: Chemo taxonomic studies in Cynodon dactylon (L.) Pers. complex II. Flavonoid patterns and ascorbic acid content.

24. Rao BS, Upadhya D, Adiga SK.,J Environ Pathol Toxicol Oncol. 2008; Protection of ionizing radiation-induced cytogenetic damage by hydroalcoholic extract of Cynodon dactylon in Chinese hamster lung fibroblast cells and human peripheral blood lymphocytes.

25.Hajzadeh Musa-Al-Reza, Behnam Rassouli Fatemeh, Khajavirad Abolfazl Mahmoudian Alireza, Pharmacognosy Research [Phcog Res] Vol 1, Issue 6, Nov-Dec, 2009 Page 431-434: The Effects of N-butanol Fraction and N-butanol Phase Remnant From 50\% Aqueous-Ethanolic Extract of Cyndon Dactylon on Calcium Oxalate Kidney Stones in Rat.

26. Atmani F, Sadki C, Aziz M, Mimouni M, Hacht B.,Urol Res. 2009 Apr: Cynodon dactylon extract as a preventive and curative agent in experimentally induced nephrolithiasis.

27. N. Mahesh and D. Brahatheeswaran. Anti-hyperglycemic Activities of Aqueous and Ethanolic Extracts Cynodon dactylon (Linn) Streptozotocin-induced Diabetic Rats . Asian Journal of Biochemistry,2007, 2: 66 -72.

28.Uncini Manganelli RE, Tomei PE. Ethno -pharmacobotanical studies of the Tuscan Archipelago. J Ethnopharmacol 1999; 65: 181-202.

29. Biswas TK, Mukherjee B. Plant medicines of Indian origin for wound healing activity. Int J Low Extreme Wounds2003;2:25-39.

30. Charde M.S., Fulzele S.V. Joshi S.B., Satturwar P. M., Dorle A.K., Wound Healing activity of Druva Ghrita. Indian J. Pharm. Sci. 2003., (65),5,482-485.

31. Babu, D.S.R., Neeharika V., Pallavi V., Reddy M.B., Antidiarrheal activity of Cynodon dactylonpers. Pharmacog. Magazine. 2009.,5, 23-27.

32. Dhar M.L., Dhar M.M., Dhawan B.N., Mehrotra B.N., Roy C., Screening of Indian plants for biological activity-Part 1. Indian J. Exp. Biol.1968,6, 232-247.

33. Patil, M.B., Jalalpure S.S., Prakash N.S., Kokate O.K., Antiulcer properties of alcoholic extract of Cynodon dactylon in rats. Acta Horticulturae. 2005.,480,115-118. 